\title{
Bio-economic assessment of sheep supplementation in marandu palisadegrass pastures
}

\section{Avaliação bioeconômica da suplementação de ovinos em pastos de capim-marandu}

\author{
Leandro Miranda ${ }^{1}$; Luciano da Silva $\mathrm{Cabral}^{2}$; Daniel Marino Guedes de Carvalho ${ }^{2}$; \\ Joadil Gonçalves de $\mathrm{Abreu}^{2}$; Rosane Claudia Rodrigues ${ }^{3}$; \\ Alexandre Lima de Souza²; Edenio Detmann; Nelcino Francisco de Paula²; \\ Arthur Behling Neto ${ }^{2 *}$; Leni Rodrigues Lima ${ }^{5}$
}

\begin{abstract}
Goal was to evaluate the effect of mineral and/or energy-protein supplementation on intake, behavior, production response, $\mathrm{pH}$, rumen ammonia and production cost of sheep. Twenty female lambs and five rumen-cannulated lambs were used to test supplementation effects on weight gain and nutritional characteristics, respectively. Treatments evaluated were: mineral mixture, supplement with 20 and $25 \%$ of crude protein offered at 0.5 and $1.0 \%$ of body weight. Supplementation at $1.0 \%$ of body weight reduced forage intake. Average daily gain were: $-58.33,-1.07,-9.53,19.27$ and $34.73 \mathrm{~g}^{2}$ day $^{-1}$ per animal, for mineral mixture, supplements with 20 and $25 \%$ of crude protein supplied at $0.5 \%$ of body weight and 20 and $25 \%$ crude protein provided at $1.0 \%$ of body weight, respectively. Rumen $\mathrm{pH}$ for all supplements was maintained above 6.20. Values of rumen ammonia nitrogen were 5.10, 9.48, 11.54, 17.51 and $22.45 \mathrm{mg} \mathrm{dL}^{-1}$ for supplements: mineral mixture, 20 and $25 \%$ of crude protein provided at $0.5 \%$ of body weight and 20 and $25 \%$ of crude protein supplied at $1.0 \%$ of body weight, respectively. The best economic return was obtained with the supplement $25 \%$ of crude protein provided at $1.0 \%$ of body weight.
\end{abstract}

Key words: Forage intake. Pasture. Rumen ammonia and pH. Weight gain.

\section{Resumo}

Objetivou-se com este estudo avaliar o efeito da suplementação mineral e/ou proteica energética no consumo, comportamento, resposta produtiva, $\mathrm{pH}$ e amônia ruminais e custo de produção de ovinos. Utilizaram-se 20 borregas e cinco borregos canulados no rúmen para avaliar os efeitos da suplementação sobre o ganho de peso e características nutricionais, respectivamente. Avaliaram-se os suplementos mistura mineral e suplementos com 20 e $25 \%$ de proteína bruta ofertados a 0,5 e $1,0 \%$ do peso corporal. A suplementação na proporção de $1,0 \%$ do peso corporal reduziu o consumo de forragem. Os ganhos médios diários foram de $-58,33 ;-1,07 ;-9,53 ; 19,27$ e $34,73 \mathrm{~g}$ animal dia ${ }^{-1}$, para os suplementos mistura mineral, 20 e $25 \%$ de proteína bruta fornecidos a $0,5 \%$ do peso corporal e 20 e $25 \%$ de proteína bruta ofertados a $1,0 \%$ do peso corporal, respectivamente. $\mathrm{O} \mathrm{pH}$ para todos os suplementos esteve acima de

\footnotetext{
${ }^{1}$ M.e, Agricultura Tropical, Universidade Federal do Mato Groso, UFMT, Cuiabá, MT, Brasil. E-mail: lmiranda@hotmail.com

2 Profs. Drs., UFMT, Cuiabá, MT, Brasil. E-mail: danielguedes14@yahoo.com.br; lucianoufmt@gmail.com; joadil@terra.com. br; alexandre@ufmt.br; nelcinodepaula@hotmail.com; arthur_behling@hotmail.com

${ }^{3}$ Prof $^{\mathrm{a}}$. Dr ${ }^{\mathrm{a}}$., Universidade Federal do Maranhão, UFM, Chapadinha, MA, Brasil. E-mail: claudiarod@gmail.com

4 Prof. Dr., Universidade Federal de Viçosa, UFV, Viçosa, MG, Brasil. E-mail: detmann@ufv.br

${ }^{5}$ M.e, Ciência Animal, UFMT, Cuiabá, MT, Brasil. E-mail: leni_rlima@hotmail.com

* Author for correspondence
} 
6,20. Os valores de nitrogênio amoniacal ruminal foram de 5,10;9,48; 11,54; 17,51 e 22,45 $\mathrm{mg} \mathrm{dL}^{-1}$ para os suplementos mistura mineral, 20 e $25 \%$ de proteína bruta fornecidos a $0,5 \%$ do peso corporal e 20 e $25 \%$ de proteína bruta fornecidos a $1,0 \%$ do peso corporal. O melhor retorno econômico foi obtido com o suplemento $25 \%$ de proteína bruta a $1,0 \%$ do peso corporal.

Palavras-chave: Amônia ruminal. Consumo de forragem. Ganho de peso. Pastagem. pH.

\section{Introduction}

Using forage plants for grazing is the most economical method to supply nutrients to a herd of sheep, ensuring that raising these animals in pasture can be profitable. When managed in order to ensure consistent feed supply to animals, especially when deficiencies observed during the dry season are fixed, weight gain of animals is attained and there is a decrease in the production cycle (FRESCURA et al., 2005).

Grasses of the genus Brachiaria are not recommended for sheep grazing, since they harbor anti-nutritional factors such as steroidal saponins (SANTOS et al., 2008) and fungus Pithomyces chartarum (TOKARNIA et al., 2000), responsible for photosensitivity in animals. However, sheep in central Brazil are essentially maintained in pastures with Brachiaria grasses. Photosensitivity problems in sheep raised in pastures with signal grass can be avoided with animal adaptation management for forage intake.

When there is competition, it is crucial that the adopted production system eliminates or mitigates periods of time when food is scarce, providing conditions for the animals that enable growth throughout the year, achieving ideal body weight at slaughter (REIS et al., 2009).

The dry season in the Midwest Region of Brazil is between May and October, and characterized by an increase in the abundance of plant stems and senescent or dead material, as well as a decrease in leaf blade production. There is also a decrease in nutritional value of material consumed by animals (BRÂNCIO et al., 2003). The limiting nutrients in animal production include nitrogen compounds, which during the dry season restrain microorganism activity in the rumen, negatively influencing forage digestibility and intake, leading to lower animal performance (DETMANN et al., 2004).

Production of growing sheep under grazing conditions should previse supplementation with concentrated (BARBOSA et al., 2003). Performance of grazing lambs can be improved by providing concentrated supplementation (ANDRADE et al., 2007). In this regard, it is important to assess the proper forage grasses for grazing sheep, as well as the protein requirements under grazing conditions.

Thus, supplementation with concentrate reduces age at slaughter, increases outcome rate and floating capital. Thus, knowledge of vegetation structure, chemical composition, with total fractions of nitrogenous and carbohydrates compounds, and observed variations throughout the year are essential to formulation of supplements that optimize intake, forage digestibility, and consequently, animal performance (REIS et al., 2009).

The goal was to evaluate dry matter intake, behavior and animal performance, $\mathrm{pH}$, ruminal ammonia nitrogen concentration and production cost in grazing sheep supplemented with two supplementation levels, 0.5 and $1.0 \%$ of body weight, and two crude protein levels in the supplements, 20 and $25 \%$, in low quality marandu palisadegrass pastures.

\section{Materials and Methods}

Trial was conducted at the Sheep Sector dependencies of Mato Grosso Federal University (UFMT) experimental farm, located in Santo Antônio de Leverger, $30 \mathrm{~km}$ from Cuiaba-MT in Brazil, starting in September and ending in November 2007, with a total of 77 experimental 
days. The experimental site was at $141 \mathrm{~m}$ above sea level, latitude $15^{\circ} 51^{\prime}$ South and longitude $56^{\circ}$ 04' West. The climate is Cwa according to Koepen classification, indicating that it is tropical, seasonal, and includes two well defined seasons, which are rainy summer (October to March) and dry winter (April to September).
Pasture area for animal performance evaluation consisted of five 1.0 ha paddocks, established with Brachiaria brizantha cv. Marandu, and also with covered feeders and water troughs. Meteorological data for the period during which the trial was conducted, as well as the two months prior to trial, were obtained from the meteorological station of UFMT (Table 1).

Table 1. Rainfall index (RI), maximum (MAT), minimum (MIT) and mean temperature (MET) during experimental period.

\begin{tabular}{lcccc}
\hline \multirow{2}{*}{ Month } & RI & MAT & MIT & MET \\
\cline { 2 - 4 } July & $(\mathrm{mm})$ & & $\left({ }^{\circ} \mathrm{C}\right)$ & \\
August & - & 36.80 & 11.70 & 24.25 \\
September & 12.50 & 39.30 & 14.00 & 26.65 \\
October & 23.30 & 40.50 & 13.20 & 26.85 \\
November & 82.40 & 41.80 & 18.10 & 29.95 \\
\hline
\end{tabular}

Source: Experimental farm meteorological station of UFMT.

Twenty purebred Santa Inês lambs were used, with an average age and initial body weight of 4.5 months and $28.68 \mathrm{~kg}$, respectively. Lambs were randomly distributed among treatments (supplements), defined as follows: mineral mixture (MM) as control; 20\% crude protein (CP) supplied at $0.5 \%$ of animal's body weight (BW); $20 \% \mathrm{CP}$ provided at $1.0 \%$ of animal's BW; $25 \% \mathrm{CP}$ supplied at $0.5 \%$ of animal's $\mathrm{BW}$ and $25 \% \mathrm{CP}$ provided at $1.0 \%$ of animal's BW. Animals were weighed at the beginning and end of the experiment, without fasting, and every 20 days to monitor performance and allow for the adjustment of supplement provision. Animals were rotated between paddocks every 14 days to reduce possible variations between availability and quality of forage among experimental paddocks. All animals were subjected to ectoparasites and endoparasites control at the beginning and the middle of the experiment, using product based on closantel, in order to maintain the number of worm eggs per gram of feces (EPG) below 500. Supplements composition based on fresh matter is shown in Table 2. Supplements (Table 2) were provided daily at $10 \mathrm{~h} 00$. Supplement remains were monitored daily in order to avoid waste and monitor intake.

Table 2. Cost of ingredients and percent composition of supplements in fresh matter basis.

\begin{tabular}{lccccc}
\hline \multirow{2}{*}{\multicolumn{1}{c}{ Ingredient }} & \multicolumn{2}{c}{ Values } & \multicolumn{3}{c}{ Supplements } \\
\cline { 2 - 5 } Corn ground grain & $\mathrm{R} \$$ ton $^{1}$ & $\mathrm{R} \$ / \mathrm{kg}$ & $\mathrm{MM}$ & $20 \% \mathrm{CP}$ & $25 \% \mathrm{CP}$ \\
Soybean meal & 350.00 & 0.35 & - & 67.00 & 54.00 \\
Mineral Mixture $^{2}$ & 700.00 & 0.70 & - & 30.00 & 43.00 \\
\hline
\end{tabular}

${ }^{1}$ Real per ton cost. ${ }^{2}$ Commercial mineral mixture for sheep (Guarantee levels per kg of product: $155 \mathrm{~g}$ calcium; $65 \mathrm{~g}$ phosphorus; 115 g sodium; 6 g magnesium; 175 mg cobalt; 100 mg copper; 175 mg iodine; 1,400 mg manganese; 42 mg nickel; 27 mg selenium; 6,000 mg zinc; $650 \mathrm{mg}$ fluorine. MM: Mineral mixture; CP: Crude protein. 
At the first day of each trial period, forage samples were collected in different paddocks by cutting, at $5 \mathrm{~cm}$ above ground, in ten areas, delimited by a metal square of $0.5 \times 0.5 \mathrm{~m}$, randomly chosen in each experimental paddock, to estimate forage mass $\left(\mathrm{kg} \mathrm{ha}^{-1}\right)$.

After collect, samples of each paddock were weighed and mixed, and from these two compost aliquots were obtained, one to assess forage total mass availability (FTMA) ( $\left.\mathrm{kg} \mathrm{ha}^{-1}\right)$ and another for the analysis of dry matter (DM), availability per hectare of: green leaf blade (DMLB), green stem (DMGS) and senescent material (DMSM). Evaluation of ingested forage by animals was performed using the manual grazing simulation technique by collecting forage samples in two diagonal lines within each paddock at the first day of each experimental period, in order to maintain the same method of sampling and reduce the variability among results. All collected material was immediately frozen at $-20^{\circ} \mathrm{C}$ for later analysis at the laboratory and all supplements were also routinely sampled.

Fecal excretion was estimated by applying chromium oxide III with the aid of a flexible applicator (plastic hose) with a piston through the esophagus. The chromium oxide was applied ( $5 \mathrm{~g}$ animal $^{-1}$ day $^{-1}$ ) from the $30^{\text {th }}$ to the $38^{\text {th }}$ day approximately at 'noon, with feces collect at $06 \mathrm{~h} 00$; $12 \mathrm{~h} 00$ and $17 \mathrm{~h} 00$ of days 36,37 and 38 , respectively. Fecal excretion estimation was performed using the equation $\mathrm{EF}_{\left(\mathrm{kg} \mathrm{day}^{-1}\right)}=\left(\mathrm{QFI}_{(\mathrm{g})} / \mathrm{CIF}_{\left(\mathrm{g} \mathrm{kg} \mathrm{dm}^{-1}\right)}\right) \times 100$, where: QIF = Quantity of supplied indicator $(\mathrm{g})$; $\mathrm{CIF}=$ Indicator concentration in feces $\left(\mathrm{g} \mathrm{kg}^{-1} \mathrm{DM}\right)$.

Voluntary intake estimation was carried out using as internal indicator indigestible neutral detergent fiber (iNDF), with the following equation: $\mathrm{CMS}_{(\mathrm{kg}}$ $\left.{ }_{\text {day }}^{-1}\right)=\left\{\left[\left(\mathrm{EF}_{\left(\mathrm{kg} \mathrm{day}^{-1}\right)} \mathrm{x}^{-1} \mathrm{CIF}_{(\mathrm{kg} \mathrm{kg}}{ }^{-1}\right)-\mathrm{IS}_{(\mathrm{kg} \text { day }}{ }^{-1}\right)\right] / \mathrm{CIFO}_{(\mathrm{kg}}$ $\left.\left.{ }_{\mathrm{kg}}^{-1}\right\}\right)+\mathrm{CMSS}_{\left(\mathrm{kg} \mathrm{day}^{-1}\right)}^{-1}$, wherein: $\mathrm{CIF}=$ indicator concentration in feces $\left(\mathrm{kg} \mathrm{kg}^{-1}\right)$; CIFO = indicator concentration in the forage $\left(\mathrm{kg} \mathrm{kg}^{-1}\right)$; CMSS = supplement dry matter intake $\left(\mathrm{kg} \mathrm{day}^{-1}\right) ; \mathrm{EF}=$ fecal excretion $\left(\mathrm{kg} \mathrm{day}^{-1}\right)$ and IS $=$ the indicator present in the supplement $\left(\mathrm{kg} \mathrm{day}^{-1}\right)$.

Besides animals used to measure the performance and behavior, a rumen-cannulated animal was allocated at each paddock to evaluate $\mathrm{pH}$ and amounts of ruminal ammonia nitrogen (N$\mathrm{NH}_{3}$ ). Cannulated animals were placed in a 5x5 latin square design, and each trial period corresponded to 14 days. From $1^{\text {st }}$ to the $13^{\text {th }}$ experimental day, animals were adapted only for supplements. Ruminal fluid was collected to determine $\mathrm{pH}$ and $\mathrm{N}-\mathrm{NH}_{3}$ on the $14^{\text {th }}$ day of the trial period. Rumen fluid was collected at time zero (prior to supplement delivery), 2, 4 and $6 \mathrm{~h}$ after supplement delivery, close to ruminal cannula opening and filtered in a beaker with the aid of two overlapping sieves of 2 $\mathrm{mm}$ porosity. The $\mathrm{pH}$ reading was performed with a digital $\mathrm{pH}$ meter immediately after material was collected. After reading $\mathrm{pH}$, an aliquot of $50 \mathrm{ml}$ was packed in a plastic vial with $1 \mathrm{ml}$ of sulfuric acid $\left(\mathrm{H}_{2} \mathrm{SO}_{4}\right)$ at ratio of $1: 1$ and frozen at $-20{ }^{\circ} \mathrm{C}$ for subsequent analysis of $\mathrm{N}-\mathrm{NH}_{3}$ quantities.

Samples of supplements and forage were analyzed at the animal nutrition laboratory of UFMT, to determine the quantities of dry matter (DM), crude protein (CP), neutral detergent fiber (NDF) according to techniques described by Silva and Queiroz (2002). Concentrations of indigestible neutral detergent fiber (iNDF) were determined using the in situ method, and were obtained after incubation for 144 hours of incubation in a rumencannulated bovine, as described by Cochran et al. (1986). Fecal chromium content was determined at the animal nutrition laboratory of Viçosa Federal University (UFV). On the $20^{\text {th }}, 40^{\text {th }}$, and $60^{\text {th }}$ experimental days, assessments of grazing animal daytime behavior were carried out by visual observation, with classified animal activities with the following terms: grazing, idleness, rumination and water troughs. Animal behavior assessments were performed every 10 minutes between $06 \mathrm{~h} 00$ and $18 \mathrm{~h} 00$, with a total evaluation of $12 \mathrm{~h}$. 
For the economic evaluation, the value per ton of each ingredient was obtained using a price quotation from the local market for three different suppliers. Supplements cost was calculated according to the amount of each ingredient included multiplied by its respective price per unit of product $(\mathrm{kg})$. Cost per day $(\mathrm{R} \$)$ was calculated by multiplying the intake of animal supplement per day by the price per $\mathrm{kg}$ of supplement. Gross margin per $\mathrm{kg}$ of gain was calculated as the difference between the cost per $\mathrm{kg}$ of product and total cost needed of the supplement for the animal to attain the quantified $\mathrm{kg}$ of gain. To calculate labor cost, it was assumed the employee hired would have the capacity to care for 500 animals, and would be compensated monthly by $\mathrm{R} \$$ 545,00 . The same labor costs were considered for supplements 20 and $25 \% \mathrm{CP}$ provided at 0.5 and $1.0 \%$ of $\mathrm{BW}$, as these supplements were provided daily. For MM (mineral mixture) troughs were filled weekly.

Analysis regarding performance, food intake and behavior of experimental animals were conducted in a completely randomized design, according to the statistical model: $\mathrm{y}_{\mathrm{ij}}=\mathrm{m}+\mathrm{t}_{\mathrm{i}}+\mathrm{e}_{\mathrm{ij}}$, where: $\mathrm{m}=$ general constant; $t_{i}=$ supplement $i$ effect, where $i$ $=1,2,3$ and 4; $\mathrm{e}_{\mathrm{ij}}=$ random error (associated with each observation), and NID assumption $\left(0, \sigma^{2}\right)$. Analysis related to $\mathrm{pH}$ and $\mathrm{N}-\mathrm{NH}_{3}$ were conducted in a latin square design, according to the statistical model yijk $=\mathrm{m}+\mathrm{Ai}+\beta \mathrm{j}+\mathrm{Pk}+$ eijk, wherein: $\mathrm{m}$ $=$ general constant; $\alpha \mathrm{i}=$ supplementation $\mathrm{i}$ effect $(\mathrm{i}$ $=1,2,3,4$ and 5$) ; \beta j=$ effect relative to animal or treatments $\mathrm{j}$ following $(\mathrm{j}=1,2,3$ and 4$) ; \mathrm{Pk}=$ effect regarding trial $\mathrm{k}$ period $(\mathrm{k}=1,2,3,4$ and 5); and eij $=$ random error associated with each observation, and NID assumption $\left(0, \sigma^{2}\right)$. Data were analyzed by analysis of variance and, for comparison of means, the Student-Newman-Keulls (SNK) test was adopted, performed through SAEG software - UFV (1995), adopting probability level of 5\%.

\section{Results and Discussion}

Average mass values of total forage (TFM), green leaf blades (GLBM), green stems (GSM) and senescent material (SMM) at pastures of 10,510; 1,750; 5,200 and 3,560 $\mathrm{kg} \mathrm{ha}^{-1}$ were observed, respectively (Figure 1). Behavior of availability data found is according to observed by Carvalho et al. (2009, 2011); Paula et al. (2010) in pasture of Brachiaria brizantha cv. Marandu. Low values observed for GLBM for the months of September and October reflects the low growth rate of forage grasses during the dry season, as well as the selective ability of sheep to consume preferably green leaf blades instead of stems, which better satisfy nutritional requirements. Despite the fact that observed forage mass throughout the trial was above the minimum limits suggested by Minson (1990) of 2,000 kg ha-1, to don't limit intake, plants consumed were characterized by a high proportion of stems and small proportion of green leaf blades, reducing forage quality (BRÂNCIO et al., 2003,) affecting animal performance (TRINDADE et al., 2007). According to Euclides et al. (2000), in tropical pastures, where there is an accumulation of senescent material, grazing pressure should be expressed as mass of green forage, especially as green leaf blades, since there is no relationship between animal performance and production per hectare when grazing pressure is calculated based on forage total dry mass (FTDM), while there is a positive relationship when the calculation is based on green dry matter (GDM). In fact, when available, animals tend to select only green leaves and refuse dried leaves and stems. 
Figure 1. Dry mass of total forage (DMTF), green leaves blade (DMGL), green stems (DMGS) and senescent material (DMSM) of marandu palisadegrass during each experimental period.

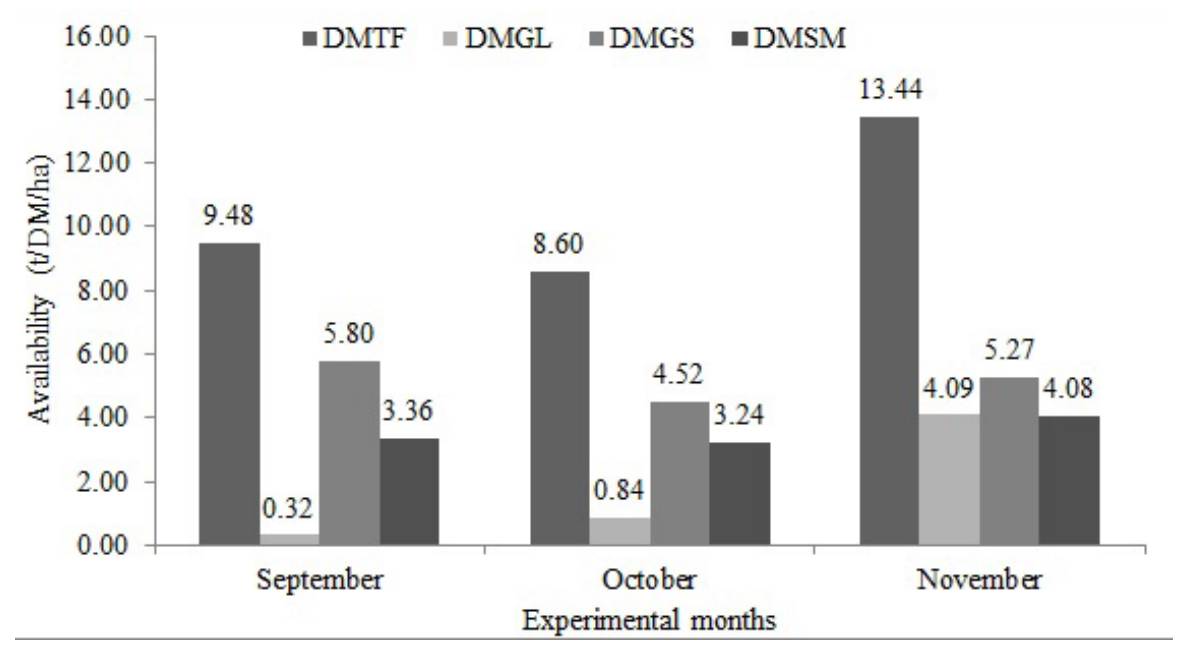

Working with forage allowance that ranged between 4 and 16\% of BW, Machado et al. (2008) observed a decrease in animal performance for lower green leaf blade offers (GLBM), despite its higher nutritional value. Thus, the negative performance of animals in this experiment receiving the control mineral mixture and supplements provided at $0.5 \%$ of BW can be attributed in part to low availability of GLBM and high proportion of GSM and SMM. The CP content (6.11\%) of grazed forage (Table 3 ) was higher than those reported by Paulino et al. (2002) and Gomes Júnior et al. (2002), which were 2.52 and $3.96 \%$ CP, respectively. However, they were closer to values found by Carvalho et al. $(2009,2011)$ who analyzed marandu palisadegrass samples obtained via simulated grazing at dry season, and obtained averages of 5.49 and $4.78 \% \mathrm{CP}$, respectively. The CP values were below the minimum required $(10 \% \mathrm{CP})$ to optimize the use of potentially digestible neutral detergent fiber ( $\mathrm{pdNDF}$ ) in the rumen (PAULINO et al., 2007; DETMANN et al., 2010), characterizing the forage as of low quality and stressing the need for supplementation with CP.

Table 3. Chemical composition of marandu palisadegrass, determined by manual grazing simulation, and supplements.

\begin{tabular}{lccc}
\hline \multirow{2}{*}{ Items } & \multicolumn{2}{c}{ Supplement } & \multirow{2}{*}{ Marandu palisadegrass ${ }^{2}$} \\
\cline { 2 - 3 } & $20 \% \mathrm{CP}$ & $25 \% \mathrm{CP}$ & 41.23 \\
Dry matter (\%) $_{\text {Crude protein }}{ }^{1}$ & 89.00 & 88.00 & 6.11 \\
Neutral detergent fiber $^{1}$ & 20.54 & 25.49 & 72.20 \\
Indigestible neutral detergent fiber $^{1}$ & 8.20 & 9.50 & 25.47 \\
\hline
\end{tabular}

${ }^{1}$ Expresed as $\%$ of dry matter; ${ }^{2}$ Average of four collections

Average NDF content observed for forage in this study was $72.20 \%$, close to those found by Euclides et al. (2009) of $70.10 \%$ in leaf blades samples, and lower than that reported by Carvalho et al. (2011) of $75.10 \%$ in simulated grazing samples. Note that supplementation use (Table 4) promoted an increase $(\mathrm{P}<0.05)$ in total dry matter intake $(\mathrm{DMI})$, compared to non-supplemented animals. However, when dry matter intake was expressed based on BW (DMIBW), there was no effect of supplement use, 
which might be due to weight decrease observed among the control group of animals, ensuring that intake expression in relation to body weight is more important.

Regarding forage intake (FDMI), only treatment comprised by supply at $0.5 \%$ of BW with $20 \% \mathrm{CP}$ differed from treatment with $1.0 \%$ of $\mathrm{BW}$. It was observed that supplementation at $1.0 \%$ of animal BW led to lower values of FDMI, which can be attributed to the substitution effect of forage grass by the supplement, confirmed by the higher value of the substitution coefficient calculated for forage by supplement (SUBCF) in the above treatments. For forage intake, Ribeiro (2008) found values of $2.7 \%$ of BW animal day ${ }^{-1}$ for individuals supplied with mineral mixture, relatively higher value than observed here. The difference could be attributed to variation in nutritional values of forage available to animals in the above study, characterized by higher CP content $(8.79 \%)$ and lower levels of iNDF $(19.35 \%)$. The iNDF is a NDF fraction with a notable effect on rumen repletion, since it is not digested, disappearing from rumen only by process of passage. Therefore, iNDF concentration in forage plants and diets is negatively related to intake. For forages DMI, Ribeiro (2008) noted that supplements use promoted expansion in daily dry matter intake, but caused a decrease in forage intake among animals that received supplements at the proportion of $1.0 \%$ of $\mathrm{BW}$, similar to what was observed in this trial.

Table 4. Mean values for total intake for supplemented sheep in marandu palisadegrass.

\begin{tabular}{lccccccc}
\hline \multirow{2}{*}{ Variable } & \multirow{2}{*}{ MM } & \multicolumn{2}{c}{$0.5 \%$ of BW } & \multicolumn{2}{c}{$1.0 \%$ of BW } & \multirow{2}{*}{ P } & \multirow{2}{*}{ CV (\%) } \\
\cline { 3 - 6 } & & $20 \% \mathrm{CP}$ & $25 \% \mathrm{CP}$ & $20 \% \mathrm{CP}$ & $25 \% \mathrm{CP}$ & & \\
\hline DMI & $555.70^{\mathrm{b}}$ & $772.44^{\mathrm{a}}$ & $680.30^{\mathrm{a}}$ & $656.66^{\mathrm{a}}$ & $738.82^{\mathrm{a}}$ & 0.009 & 10.48 \\
DMIBW & $2.44^{\mathrm{a}}$ & $2.87^{\mathrm{a}}$ & $2.59^{\mathrm{a}}$ & $2.28^{\mathrm{a}}$ & $2.53^{\mathrm{a}}$ & $\mathrm{Ns}$ & 13.79 \\
FDMI & $555.70^{\mathrm{ab}}$ & $637.04^{\mathrm{a}}$ & $551.00^{\mathrm{ab}}$ & $375.66^{\mathrm{c}}$ & $452.32^{\mathrm{bc}}$ & 0.002 & 14.01 \\
FDMIBW & $2.44^{\mathrm{a}}$ & $2.37^{\mathrm{a}}$ & $2.10^{\mathrm{a}}$ & $1.31^{\mathrm{b}}$ & $1.55^{\mathrm{ab}}$ & 0.002 & 18.03 \\
CFRS $^{1}$ & -- & - & 0.04 & 0.64 & 0.36 & - & - \\
DMAD & 46.74 & 50.75 & 50.02 & 45.51 & 46.60 & - & - \\
\hline
\end{tabular}

${ }^{1}$ Coefficient of forage replacement ( $\mathrm{g}$ forage per $\mathrm{g}$ supplement); Means followed by the same letter at line do not differ by SNK test at $5 \%$ probability; $\mathrm{CV}=$ coefficient of variation; $\mathrm{MM}=$ Mineral mixture; $\mathrm{BW}=$ body weight $\mathrm{CP}=$ crude protein; $\mathrm{DMI}=$ dry matter intake $\left(\mathrm{g}_{\text {animal }}\right.$ day $\left.^{-1}\right)$ FDMI $=$ total dry matter intake $(\%$ of body weight $)$; FDMI = forage intake $\left(\mathrm{g}\right.$ animals day $\left.{ }^{-1}\right)$; FDMIBW $=$ forage intake ( $\%$ of body weight); CFRS = coefficient of forage replacement by supplement; DMAD = coefficient of dry matter apparent digestibility.

The $\mathrm{N}-\mathrm{NH}_{3}$ concentration for animals receiving only mineral mix was $5.10 \mathrm{mg} \mathrm{dL}^{-1}$, which was lower than in any other supplement used (Table 5). There was no statistical difference $(\mathrm{P}<0.05)$ for $\mathrm{N}-\mathrm{NH}_{3}$ concentration when 20 and $25 \% \mathrm{CP}$ was provided at $0.5 \%$ of BW, however the latter differed from mineral mixture and supplementation of $25 \% \mathrm{CP}$ provided at $1.0 \%$ of $\mathrm{BW}$, which reached $\mathrm{N}-\mathrm{NH}_{3}$ concentration of $22.45 \mathrm{mg} \mathrm{dL}^{-1}$. Sampaio et al. (2010) found that $\mathrm{N}-\mathrm{NH}_{3}$ concentration of $5.00 \mathrm{mg} \mathrm{dL}^{-1}$ were enough to maintain adequate microbial activity in the rumen of ruminants fed with low quality tropical grasses.
However, the same authors found that in order to maximize low quality forage use, it is necessary to maintain levels of ammonia at $10.00 \mathrm{mg} \mathrm{dL}^{-}$ ${ }^{1}$. In this context, the $\mathrm{N}_{-} \mathrm{NH}_{3}$ concentrations for supplements $25 \% \mathrm{CP}$ provided at $0.5 \%$ of $\mathrm{BW}$ and $20 \%$ CP supplied at $1.0 \%$ of BW, provide sufficient amounts of ruminal ammonia for fiber degradation to be maximized. The $\mathrm{N}-\mathrm{NH}_{3}$ concentration in the supplement $25 \%$ CP supplied at to $1.0 \%$ of BW was higher than recommended by Leng (1990), of 20.00 $\mathrm{mg} \mathrm{dL}-1$ and found to maximize voluntary intake under tropical conditions. 
Table 5. Mean values for $\mathrm{pH}$ and concentration of ruminal ammonia nitrogen $\left(\mathrm{N}^{-} \mathrm{NH}_{3}\right)$ in $\mathrm{mg} \mathrm{dL}^{-1}$ for sheep supplemented in low quality marandu palisadegrass pastures.

\begin{tabular}{|c|c|c|c|c|c|c|}
\hline \multirow{3}{*}{ Variable } & \multicolumn{5}{|c|}{ Supplements } & \multirow{3}{*}{ CV $(\%)$} \\
\hline & \multirow{2}{*}{ MM } & \multicolumn{2}{|c|}{$0.5 \%$ of $\mathrm{BW}$} & \multicolumn{2}{|c|}{$1.0 \%$ of $\mathrm{BW}$} & \\
\hline & & $20 \% \mathrm{CP}$ & $25 \% \mathrm{CP}$ & $20 \% \mathrm{CP}$ & $25 \% \mathrm{CP}$ & \\
\hline $\mathrm{pH}$ & $6.49^{\mathrm{a}}$ & $6.33^{\mathrm{bc}}$ & $6.42^{\mathrm{ab}}$ & $6.21^{\mathrm{d}}$ & $6.29^{\mathrm{cd}}$ & 2.74 \\
\hline \multirow[t]{3}{*}{$\mathrm{N}-\mathrm{NH}_{3}$} & $5.10^{c}$ & $9.48^{\mathrm{b}}$ & $11.54^{\mathrm{b}}$ & $17.51^{\mathrm{ab}}$ & $22.45^{\mathrm{a}}$ & 70.00 \\
\hline & \multicolumn{5}{|c|}{ Collect times (Hours) } & \\
\hline & 0 & 2 & 4 & 6 & Regression & \\
\hline $\mathrm{pH}$ & 6.56 & 6.31 & 6.21 & 6.15 & $Y=6.528-0.0607 X$ & 1.95 \\
\hline $\mathrm{N}-\mathrm{NH}_{3}$ & 14.74 & 17.74 & 17.42 & 14.11 & $Y=16.00$ & 55.06 \\
\hline
\end{tabular}

Means followed by the same letter at line do not differ by SNK test at 5\% probability; $\mathrm{CV}=$ coefficient of variation; MM = Mineral mixture; $\mathrm{BW}=$ body weight; $\mathrm{CP}=$ crude protein.

No significant differences were found $(\mathrm{P}>0.05)$ for $\mathrm{pH}$ values for supplements (Table 5), however a linear decrease effect was observed regarding collection times. All $\mathrm{pH}$ values found in this study were higher than reported by Hoover (1986) of 6.20, and determined to be the limit for fibrolytic microorganism activity. Carvalho et al. (2011), supplementing sheep in low quality marandu palisadegrass pastures, also observed no change in ruminal $\mathrm{pH}$, even when the supplement used was based almost exclusively on corn (starch), highlighting the high fiber effectiveness of tropical pastures. In studies conducted in Brazil, it was shown that even high levels of supplements provided to grazing animal do not cause severe disorders to rumen environment as to $\mathrm{pH}$ (DETMANN et al., 2005). According to Paulino et al. (2007), this effect can be attributed to the high fiber effectiveness of tropical grasses under grazing.

There was no significant difference in animal behaviour $(\mathrm{P}>0.05)$. It was numerically observed that there was an $11 \%$ decrease in grazing time and $9 \%$ increase in idleness time (Figure 2) for animals supplemented with $25 \% \mathrm{CP}$ at $1.0 \%$ of BW, compared to animals receiving mineral mixture. This reduction is possibly associated with the substitution effect of higher level of supplementation on forage dry matter intake, an argument also supported by the replacement coefficient of 0.36 found for supplement $25 \% \mathrm{CP}$ at $1.0 \%$ of BW (Table 4 ).

Similar behaviour was observed for supplement $25 \% \mathrm{CP}$ at $0.5 \%$ of BW with time spent grazing $8 \%$ lower and idleness time $7 \%$ higher than animals receiving mineral mixture. Working with sheep in an Aruana grass pasture fed with supplements containing $15 \%, 20 \%, 25 \%$ and $30 \% \mathrm{CP}$ provided at $1.0 \%$ of BW, Ribeiro (2008) observed a decrease in grazing time and increase in idleness time for supplemented animals compared to those receiving only mineral mixture.

It was found that only pasture at dry season did not reach maintenance requirements, since there was a daily weight loss of $-58.33 \mathrm{~g}$ animal day $^{-1}$ (Table 6). However, even the supplements offer in proportion of $0.5 \% \mathrm{BW}$ with 20 and $25 \%$ of CP did not allow positive performance, which probably would not have been enough to alter the low nutritional value of available forage to animals, characterized by high forage mass, but with reduced green leaves availability and high proportion of stems and senescent material. 
Figure 2. Times (in \% of total daily activities) spent with activities of grazing (GRA), rumination (RUM), idleness (IDL), intake of mineral mixture (IMM), supplement (ISU) and water (IWA) by sheep in supplemented grazing.

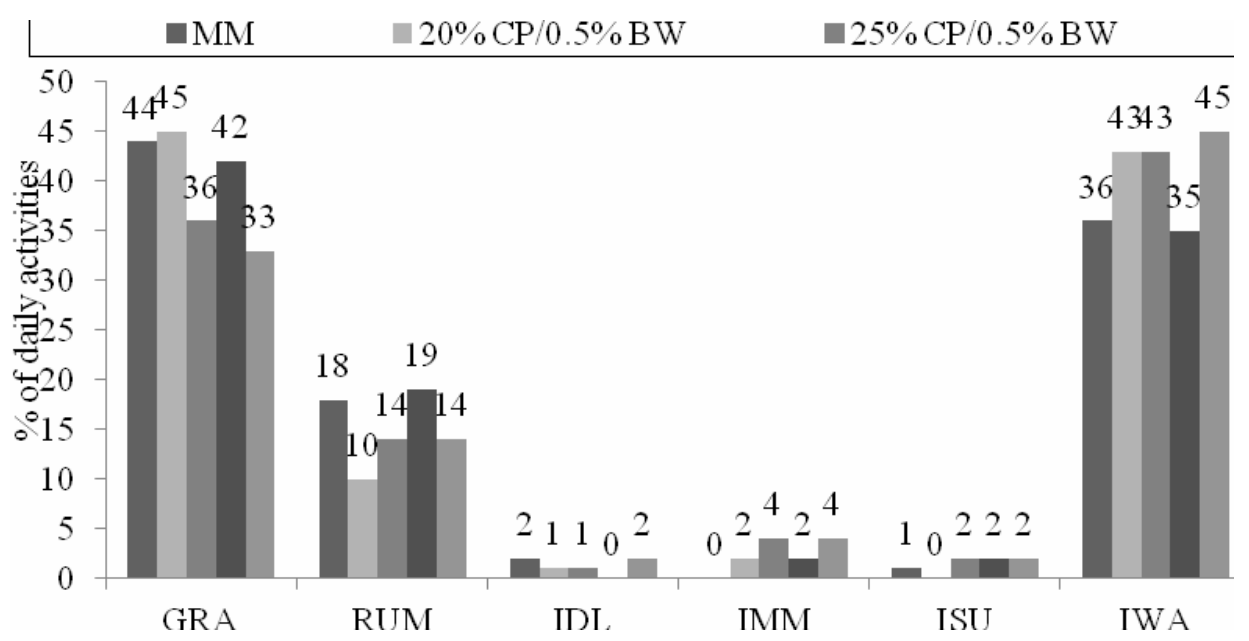

Table 6. Mean values for measured lamb parameters.

\begin{tabular}{|c|c|c|c|c|c|c|}
\hline \multirow{2}{*}{ Items } & \multirow{2}{*}{$\mathrm{MM}^{1}$} & \multicolumn{2}{|c|}{$0.5 \%$ of $\mathrm{BW}$} & \multicolumn{2}{|c|}{$1.0 \%$ of $\mathrm{BW}$} & \multirow{2}{*}{ CV $(\%)$} \\
\hline & & $20 \% \mathrm{CP}$ & $25 \% \mathrm{CP}$ & $20 \% \mathrm{CP}$ & $25 \% \mathrm{CP}$ & \\
\hline IBW $(\mathrm{kg})$ & 28.90 & 28.25 & 28.52 & 29.38 & 28.38 & -- \\
\hline FBW (kg) & 24.51 & 28.17 & 27.81 & 30.82 & 30.99 & -- \\
\hline TWG $\left(\mathrm{kg}\right.$ animal $\left.^{-1}\right)$ & -4.39 & -0.08 & -0.71 & 1.44 & 2.61 & -- \\
\hline ADG (g animal day $\left.{ }^{-1}\right)$ & $-58.33 d$ & $-1.07 \mathrm{c}$ & $-9.53 \mathrm{~d}$ & $19.27 b$ & $34.73 \mathrm{a}$ & 43.85 \\
\hline DWG (g animal day ${ }^{-1}$ ) & --- & -57.26 & -48.80 & 77.60 & 93.06 & -- \\
\hline ASI (g animal day $\left.{ }^{-1}\right)$ & 11.42 & 135.40 & 129.30 & 281.00 & 286.50 & -- \\
\hline
\end{tabular}

Means followed by the same letter at line do not differ by SNK test at $5 \%$ probability; $\mathrm{CV}=$ coefficient of variation; ${ }^{1} \mathrm{MM}=$ Mineral mixture; $\mathrm{BW}=$ body weight; $\mathrm{CP}=$ crude protein. $\mathrm{IBW}=$ initial body weight, $\mathrm{FBW}=$ final body weight, $\mathrm{TWG}=$ total weight gain, $\mathrm{ADG}=$ average daily gain, $\mathrm{DWG}=$ differential weight gain related to mineral mixture and average supplement intake (ASI).

Ribeiro (2008) observed that as a result of higher total dry matter intake, supplemented animals had a better performance ( $88 \mathrm{~g}$ animal day $\left.^{-1}\right)$ compared to animals fed only with mineral mixture $(25 \mathrm{~g}$ animal day $\left.^{-1}\right)$. However, it should be noted that this author did not observe weight loss in animals receiving mineral mixture and also reported that supplementation with $23 \% \mathrm{CP}$ led to a higher animal weight gain.

Performance of animals fed only using the pasture and mineral mixture, at this work, was well below the $35 \mathrm{~g}$ animal day ${ }^{-1}$ reported by Barbosa et al. (2003), for lambs maintained in pastures of Aruana and Tanzania grass with intermittent stocking. According to these authors, Aruana and
Tanzania grass at vegetative stage did not meet the nutritional requirements of growing animals, leading to unsatisfactory daily weight gain. However, it should be noted that supplementation with 20 and $25 \%$ CP supplied at $0.5 \%$ of BW led to a weight loss decrease of 57.26 and $48.80 \mathrm{~g}$ animal day $^{-1}$, compared to only mineral mixture. Only supplementation equivalent to $1.0 \%$ of $\mathrm{BW}$ led to a positive performance of 19.27 and $34.73 \mathrm{~g}$ animal day $^{-1}$, respectively, for supplements with 20 and $25 \% \mathrm{CP}$.

Even without observing positive performance of animals in treatments at $0.5 \%$ of BW, supplement use resulted in reduced weight loss, in the above treatments, or led to $\mathrm{ADG}(1.0 \%$ of $\mathrm{BW})$. It is 
interesting to note that animals provided with supplement are younger when slaughtered compared to non-supplemented. Better performance of supplemented animals can be attributed to higher daily dry matter intake compared to nonsupplemented animals, allowing an increase in supply of protein (amino acids) and energy (volatile fatty acids) precursors to animals. Similarly, it can be inferred that for supplemented animals, there were higher nitrogen $(\mathrm{N})$ compounds available for ruminal microflora growth, maintaining ruminal ammonia nitrogen levels above $10 \mathrm{mg} \mathrm{dL}^{-1}$, proposed by Sampaio et al. (2010) and Leng (1990), ranging from 13.10 to $22.45 \mathrm{mg} \mathrm{dL}^{-1}$ (Table 5 and 6) in supplemented animals, which probably led to an increase of fibrous carbohydrate digestion in the rumen and microbial protein flow to the abomasum. These last events may be due to an increase in performance of supplemented animals. There was no effect of interaction between supplement supply and $\mathrm{CP}$ content on animals ADG $(\mathrm{P}>0.05)$.

Although the daily cost of supplementing with mineral mixture was lower than for other supplements, the mineral mixture led to a gross margin of -0.22 real animal day $^{-1}$, due to a weight loss of $58.33 \mathrm{~g}$ animal day ${ }^{-1}$ (Table 7). For all levels of used supplementation and $\mathrm{CP}$, a negative gross margin was obtained. For supplements of 20 and $25 \%$ $\mathrm{CP}$ at $0.5 \%$ of $\mathrm{BW}$, negative gross margin resulted from the combination of supplement cost and weight loss of animals, additionally a higher labor cost was incurred due to daily supplementation of animals. For supplements provided at $1.0 \%$ of $\mathrm{BW}$, despite weight gains of 19.27 and $34.73 \mathrm{~g}$ animal day $^{-1}$ for $\mathrm{CP}$ levels of 20 and $25 \%$, respectively, gross margins were -0.10 and -0.07 , due to higher supplementation level and low response levels to supplementation in relation to mineral mixture or supplements of 20 and $25 \% \mathrm{CP}$ at $0.5 \%$ of BW. Carvalho et al. (2011), found that supplementing sheep at $0.4 \%$ of $\mathrm{BW}$ in low quality marandu palisadegrass pastures, led to a positive gross margin of 0.24 and 2.17 real per $\mathrm{kg}$ BW gain for animals receiving multiple or protein supplement, respectively, compared to mineral mixture. According to this author, positive economic performance is due to high differential gain between animals supplemented and those receiving only mineral mixture, combined with a lower level of supplementation and use of self-control intake supplements, where the animal regulates its own daily supplement intake, which reduces the impact of labor cost on production.

Table 7. Economic evaluation of sheep supplementation in marandu palisadegrass pastures.

\begin{tabular}{|c|c|c|c|c|c|}
\hline \multirow{3}{*}{ Economic indicators } & \multirow{3}{*}{$\mathrm{MM}$} & \multicolumn{4}{|c|}{ Supplements } \\
\hline & & \multicolumn{2}{|c|}{$0.5 \%$ of BW } & \multicolumn{2}{|c|}{$1.0 \%$ of BW } \\
\hline & & $20 \% \mathrm{CP}$ & $25 \% \mathrm{CP}$ & $20 \% \mathrm{CP}$ & $25 \% \mathrm{CP}$ \\
\hline Supplement intake $\left(\mathrm{kg} \mathrm{day}^{-1}\right)$ & 0.01142 & 0.1354 & 0.1293 & 0.281 & 0.2865 \\
\hline Cost per day with supplement $(\mathrm{R} \$)$ & 0.015 & 0.065 & 0.068 & 0.136 & 0.152 \\
\hline Cost per day with labor (R\$) & 0.005 & 0.036 & 0.036 & 0.036 & 0.036 \\
\hline Daily cost (R\$) & 0.020 & 0.101 & 0.104 & 0.172 & 0.188 \\
\hline $\mathrm{ADG}\left(\mathrm{kg} \mathrm{day}^{-1}\right)$ & -0.05833 & -0.0011 & -0.00953 & 0.01927 & 0.03473 \\
\hline Income $\left(\mathrm{R} \$ \text { day }^{-1}\right)^{1}$ & -0.2042 & -0.0037 & -0.0334 & 0.0674 & 0.1216 \\
\hline Gross margin $\left(\mathrm{R} \$\right.$ day $\left.^{-1}\right)$ & -0.22 & -0.11 & -0.14 & -0.10 & -0.07 \\
\hline
\end{tabular}

${ }^{1}$ Values considered for kilogram sale of body weight, $\mathrm{R} \$ 3.50 . \mathrm{MM}=$ Mineral mixture; $\mathrm{BW}=$ body weight; $\mathrm{CP}=$ crude protein. 


\section{Conclusions}

1. Use of supplements with 20 and $25 \% \mathrm{CP}$ provided at $1.0 \%$ of $\mathrm{BW}$ in low quality marandu palisadegrass pastures increase total dry matter intake and decrease forage dry matter intake.

2. Sheep supplementation in low quality marandu palisadegrass pastures can increase average daily weight gain in lambs.

3. Supplementation offer levels of 0.5 and $1.0 \%$ of BW for sheep in low quality marandu palisadegrass pastures do not reduce ruminal $\mathrm{pH}$ to levels below 6.20. Supplements 20 and $25 \% \mathrm{CP}$ provided at $1.0 \%$ of BW and supplement 25\% CP supplied at $0.5 \%$ of BW increase availability of ruminal ammonia nitrogen to levels above $10.00 \mathrm{mg} \mathrm{dL}^{-1}$.

4. Use of supplements with 20 or $25 \% \mathrm{CP}$ provided at 0.5 and $1.0 \%$ of BW for sheep in low quality pastures reduces grazing time. The best economic result was obtained with supplementation of $25 \% \mathrm{CP}$ provided at $1.0 \%$ of $\mathrm{BW}$.

\section{References}

ANDRADE, I. S.; SOUZA, B. B.; PEREIRA FILHO, J. M.; SILVA, A. M. A. Parâmetros fisiológicos e desempenho de ovinos Santa Inês submetidos a diferentes tipos de sombreamento e a suplementação em pastejo. Ciência e Agrotecnologia, Lavras, v. 31, n. 2, p. 540-547, 2007.

BARBOSA, C. M. P.; BUENO, M. S.; CUNHA, E. A.; SANTOS, L. E.; ESTRADA, L. H. C.; QUIRINO, C. R.; SILVA, J. F. C. Consumo voluntário e ganho de peso de borregas das raças Santa Inês, Suffolk e Ile de France, em pastejo rotacionado sobre Panicum maximum Jacq. Cvs. Aruana ou Tanzânia. Boletim Indústria Animal, Nova Odessa, v. 60, n. 1, p. 55-62, 2003.

BRÂNCIO, P. A.; EUCLIDES, V. P. B.; NASCIMENTO JUNIOR, D.; FONSECA, D. M.; ALMEIDA, R. G.; MACEDO, M. C. M.; BARBOSA, R. A. Avaliação de três cultivares de Panicum maximum Jacq. sob pastejo: comportamento ingestivo de bovinos. Revista Brasileira de Zootecnia, Viçosa, MG, v. 32, n. 5, p. 1045-1053, 2003.
CARVALHO, D. M. G.; CABRAL, L. S.; ZERVOUDAKIS, J. T.; ARNOLDO, T. L. Q.; BENATTI, J. M. B.; KOSCHECK, J. F. W.; PIONA, M. N. M.; OLIVEIRA, A. A. Suplementos para ovinos mantidos em pastos de capim-marandu. Pesquisa Agropecuária Brasileira, Brasília, v. 46, n. 2, p. 196-204, 2011.

CARVALHO, D. M. G.; ZERVOUDAKIS, J. T.; CABAL, L. S.; PAULA, N. F.; MORAES, E. H. B. K.; OLIVEIRA, A. A.; KOSCHECK, J. F. W. Fontes de energia em suplementos múltiplos para recria de bovinos em pastejo no período da seca: desempenho e análise econômica. Revista Brasileira de Saúde e Produção Animal, Salvador, v. 10, n. 3, p. 760-773, 2009.

COCHRAN, R. C.; ADAMS, D. C.; WALLACE, J. D.; GALYEAN, M. L. Predicting digestibility of different diets with internal markers: evaluation of four potential markers. Journal of Animal Science, Champaign, v. 63, n. 5, p. 1476-1483, 1986.

DETMANN, E.; PAULINO, M. F.; ZERVOUDAKIS, J. T.; CECON, P. R.; VALADARES FILHO, S. C.; GONÇALVES, L. C.; CABRAL, L. S.; MELO, A. J. N. Níveis de proteína em suplementos para terminação de bovinos em pastejo durante a época seca: desempenho produtivo e características de carcaça. Revista Brasileira de Zootecnia, Viçosa, MG, v. 33, n. 1, p. 169-180, 2004.

DETMANN, E.; PAULINO, M. F.; VALADARES FILHO, S. C. Otimização do uso de recursos forrageiros basais. In: SIMPÓSIO DE PRODUÇÃO DE GADO DE CORTE, 7., 2010, Viçosa, MG. Anais... Viçosa, MG: SIMCORTE, 2010. CD-ROM.

DETMANN, E.; PAULINO, M. F.; VALADARES FILHO, S. C.; CECON, P. R.; ZERVOUDAKIS, J. T.; CABRAL, L. S.; GONÇALVES, L. C.; VALADARES, R. F. D. Níveis de proteína em suplementos para terminação de bovinos em pastejo durante o período de transição seca/águas: digestibilidade aparente e parâmetros do metabolismo ruminal e dos compostos nitrogenados. Revista Brasileira de Zootecnia, Viçosa, MG, v. 34, n. 4, p. 1380-1391, 2005.

EUCLIDES, V. B. P.; CARDOSO, E. G.; MACEDO, M. C. M.; OLIVEIRA, M. P. Consumo voluntário de Brachiaria decumbens cv. Basilisk e Brachiaria brizantha cv. Marandu sob pastejo. Revista Brasileira de Zootecnia, Viçosa, MG, v. 29, n. 6, p. 2200-2208, 2000. Suplemento 2 .

EUCLIDES, V. B. P.; MACEDO, M. C. M.; VALLE, C. B.; DIFANTE, G. S.; BARBOSA, R. A.; CACERE, E. R. Valor nutritivo da forragem e produção animal em pastagens de Brachiaria brizantha. Pesquisa Agropecuária Brasileira, Brasília, v. 44, n. 1, p. 98-106, 2009. 
FRESCURA, R. B. M.; PIRES, C. C.; ROCHA, M. G.; SILVA, J. H. S.; MULLER, L. Sistemas de alimentação na produção de cordeiros para abate aos $28 \mathrm{~kg}$. Revista Brasileira de Zootecnia, Viçosa, MG, v. 34, n. 4, p. 12671277, 2005.

GOMES JÚNIOR, P.; PAULINO, M. F.; DETMANN, E.; VALADARES FILHO, S. C.; ZERVOUDAKIS, J. T.; LANA, R. P. Desempenho de novilhos mestiços na fase de crescimento suplementados durante a época seca. Revista Brasileira de Zootecnia, Viçosa, MG, v. 31, n. 1, p. 139-147, 2002.

HOOVER, W. H. Chemical factors involved in ruminal fiber digestion. Journal of Dairy Science, Champaign, v. 69, n. 10, p. 2755-2766, 1986.

LENG, R. A. Factors affecting the utilization of poorquality forages by ruminants particularly under tropical conditions. Nutrition Research Review, Belfaste, v. 3, n. 1, p. 277-303, 1990.

MACHADO, L. A. Z.; FABRÍCIO, A. C.; GOMES, A.; ASSIS, P. G. G.; LEMPP, B.; MARASCHIN, G. E. Desempenho de animais alimentados com lâminas foliares, em pastagem de capim marandu. Pesquisa Agropecuária Brasileira, Brasília, v. 43, n. 11, p. 16091616, 2008.

MINSON, D. J. Forage in ruminant nutrition. Queensland: Academic Press, 1990. 483 p.

PAULA, N. F.; ZERVOUDAKIS, J. T.; CABRAL, L. S.; CARVALHO, D. M. G.; HATAMOTO-ZERVOUDAKIS, L. K.; MORAES, E. H. B. K.; OLIVEIRA, A. A. Frequência de suplementação e fontes de proteína para recria de bovinos em pastejo no período seco: desempenho produtivo e econômico. Revista Brasileira de Zootecnia, Viçosa, MG, v. 39, n. 4, p. 873-882, 2010.

PAULINO, M. F.; DETMANN, E.; VALADARES FILHO, S. C. Suplementação animal em pasto: energética ou protéica? In: SIMPÓSIO DE FORRAGICULTURA E PASTAGEM, 2007, Viçosa, MG. Anais... Viçosa, MG: SIMFOR, 2007. CD-ROM.

PAULINO, M. F.; DETMANN, E.; VALADARES FILHO, S. C.; LANA, R. P. Soja grão e caroço de algodão em suplementos múltiplos para terminação de bovinos mestiços em pastejo. Revista Brasileira de Zootecnia, Viçosa, MG, v. 31, n. 1, p. 484-491, 2002. Suplemento.
REIS, R. A.; RUGGIERI, A. C.; CASAGRANDE, D. R.; PÁSCOA, A. G. Suplementação da dieta de bovinos de corte como estratégia do manejo das pastagens. Revista Brasileira de Zootecnia, Viçosa, MG, v. 38, p. 147-159, 2009. Suplemento Especial.

RIBEIRO, P. P. O. Niveis de proteina em suplementos múltiplos para ovinos manejados em pastagem de Panicum maximum Jaqc cv. Aruana na época seca. 2008. Dissertação (Mestrado em Ciência Animal) - Faculdade de Agronomia e Medicina Veterinária. Universidade Federal de Mato Grosso, Cuiabá.

SAMPAIO, C. B.; DETMANN, E.; PAULINO, M. F.; VALADARES FILHO, S. C.; SOUZA, M. A.; LAZZARINI, I.; PAULINO, P. V. R.; QUEIROZ, A. C. Intake and digestibility in cattle fed low-quality tropical forage and supplemented with nitrogenous compounds. Tropical Animal Health and Production, Edinburgh, v. 42, n. 7, p. 1471-1479, 2010.

SANTOS, J. C. A.; RIET-CORREA, F.; SIMÕES, S. V. D.; BARROS, C. S. L. Patogênese, sinais clínicos e patologia das doenças causadas por plantas hepatotóxicas em ruminantes e eqüinos no Brasil. Pesquisa Veterinária Brasileira, Brasília, v. 28, n. 1, p. 1-14, 2008.

SILVA, D. J.; QUEIROZ, A. C. Análise de alimentos: métodos químicos e biológicos. 3. ed. Viçosa, MG: Universidade Federal de Viçosa, 2002. 165 p.

TOKARNIA, C. H.; DÖBEREINER, J.; PEIXOTO, P. V. Plantas tóxicas do Brasil. Rio de Janeiro: Helianthus, 2000. $320 \mathrm{p}$.

TRINDADE, J. K.; SILVA, S. C.; SOUZA JUNIOR, S. J.; GIACOMINI, A. A.; ZEFERINO, C. V.; GUARDA, V. D. A.; CARVALHO, P. C. F. Composição morfológica da forragem consumida por bovinos de corte durante o rebaixamento do capim marandu submetido a estratégias de pastejo rotativo. Pesquisa Agropecuária Brasileira, Brasília, v. 42, n. 6, p. 883-890, 2007.

UNIVERSIDADE FEDERAL DE VIÇOSA - UFV. SAEG - Sistema de análises estatísticas e genética. Viçosa, MG: Editora UFV, 1995. (Manual do usuário). 